\title{
The Interaction Level of High School Students with Distance Learning in a Saudi Context
}

\author{
Dr. Adam Shami Abdu Al-Amri \\ Al-Qunfudah Educational Directorate, Saudi Arabia
}

\begin{abstract}
The present study aimed at exploring the interaction level of high school students with distance learning in a Saudi context. The study was conducted in Al-Qunfudah Educational Directorate in the Kingdom of Saudi Arabia. An online questionnaire was submitted to high school students and the number of respondents reached (1013) male and female students. The results of this study showed that the overall level of interaction of high school students with distance learning was high, including student-content interaction, student-teacher interaction, student-platform interaction and student-student interaction. It was also found that there were statistically significant differences in the level of interaction with distance learning due to gender differences among high school students and those differences were in favor of female students. In light of these results, some recommendations were presented.
\end{abstract}

Keywords: Interaction Level, Distance Learning, High School Students.

DOI: $10.7176 / \mathrm{JEP} / 11-17-16$

Publication date:June 30th 2020

\section{Introduction}

A school is one of the main components of the educational process, through which students can interact with their teachers, classmates and the learning materials. Due to the COVID-19 pandemic, most countries around the world have temporally closed schools and shifted from relying on school as a conventional learning environment to distance learning environments to, on the one hand, limiting the spread of this pandemic in human communities, and, on the other hand, ensuring continuity in learning (UNESCO, 2020).

The Kingdom of Saudi Arabia, represented by the Ministry of Education, has made great efforts to provide many options for distance learning, to restrict the spread of this pandemic and to promote the continuity of education and learning processes (Strategic Gears, 2020). In K-12 schools, the most popular distance learning options offered by the Ministry of Education included the Future Gate, Unified Education System, Educational Ain Channels on TV, and Educational Ain Channel on YouTube. Despite these Saudi educational efforts during this crisis, previous research emphasized the importance of studying interaction in online learning environments, which would help to improve the quality of distance learning and lead to achieve the learning objectives (Blaine, 2019; Suwono and Dewi, 2019; Turley and Graham, 2019).

Interaction in online environment is a learner-centered process. According to Wagner (1994, p. 8), interaction in educational context can be described as an event that takes place between a learner and the learner's environment. Moreover, Wanstreet (2006) introduced three definitions for interaction in online learning environments including an instructional exchange, computer-mediated communication, and social/psychological connection. In distance learning environments, the learners have four levels of interactions including the interaction of the learners with the instructor, the content, their peers and the online learning system (Bouhnik and Marcus, 2006; Moore, 1989).

Interaction is an important factor in facilitating the distance learning process. Online interaction helps to foster learner motivation, science communication, higher order thinking skills and learning outcomes (Suwono \& Dewi, 2019). Students should be conscious of their level of online interaction (Blaine, 2019). Higher levels of interaction will raise student satisfaction with online courses (Turley and Graham, 2019). Therefore, the interaction levels need to be introduced, managed and evaluated in distance learning contexts.

There is a growing body of literature identifying the importance of studying the interaction levels of students in different online learning settings (Borup, 2016; Borup, Graham and Davies, 2013; Kuo, Walker, Schroder and Belland, 2014) while little is known about these levels in Saudi high schools. This study addressed this gap by reporting the interaction levels of high school students in Saudi Arabia with distance learning. Understanding these interaction levels, however, may improve the efficiency and effectiveness of developing better online courses for high school students, which eventually contribute to better learning outcomes. Therefore, this study came to answer the following two questions: (1) What is the extent of the interaction level of high school students with distance learning in a Saudi context? and (2) are there any statistical differences in the responses of high school students in a Saudi context regarding the interaction levels with distance learning related to gender differences? 


\section{Literature Review}

Unlike face-to-face interaction, students in distance learning environments need different tools to interact with the online learning system, the teacher, the content and their peers. During the COVID-19 pandemic, all high school students in Saudi Arabia used distance learning platforms and channels such as the Future Gate, Unified Education System, Educational Ain Channels on TV, and Educational Ain Channel on YouTube to complete their entire learning at home. Using these platforms and channels increased interaction levels throughout the distance learning process. Alshehri (2017) addressed the participation of high school students in online homework in Saudi Arabia in his study but nothing was reported about the levels of online interaction in this research.

In different online learning contexts, previous studies addressed different levels of high school students' interaction. Zucker (2005) conducted a study to investigate student-student interaction in a virtual high school and the author found that this type of interaction is an important motivational factor in online learning environments. In another virtual high school in the U.S., Hawkins, Graham, Sudweeks and Barbour (2013) discussed the student-teacher interaction and they found that higher quality and frequency of this interaction would help the students to complete online courses.

Moreover, Borup et al. (2013) studied three levels of interaction at a virtual high school in the U.S. including learner-content interaction, learner-teacher interaction, and learner-learner interaction. They found that a large majority of high school students perceived these interaction levels as educational and motivational.

In another online high school in the U.S., Borup (2016) reported the perceptions of teachers about learnerlearner interaction and the author found that this kind of interaction is a way to help students engage socially in the learning environment. Turley and Graham (2019) discussed student-teacher and student-content interactions at an online high school in the U.S. and they found that high school students perceive higher levels of these interactions.

In a recent study conducted in an online high school setting in Midwestern United States, Zhang and Lin (2020) discussed the relationship between online learning satisfaction and three types of interactions included student-content interaction, student-teacher interaction and student-student interaction. They found that there is a positive relationship between online learning satisfaction and student-content interaction. They emphasized the importance of student-content interaction in online high school settings.

In light of the above, previous studies discussed different interaction levels of high school students in different online learning contexts but little is known about those levels at high schools in Saudi Arabia. Therefore, the present study focused mainly on the interaction level of high school students with distance learning in the Kingdom of Saudi Arabia, including student-platform interaction, student-content interaction, student-teacher interaction and student-student interaction.

\section{Methodology}

This study adopted a descriptive survey-based approach, which is suitable for achieving the main purpose of this study, which sought to discover the interaction level of high school students with distance learning in a Saudi context.

\subsection{Population and Participants}

The target population of this study consisted of all high school students in Al-Qunfudah Educational Directorate in the Kingdom of Saudi Arabia during the school year 2019/2020 and the number of participants in this study reached (1013) male and female students who responded to an online questionnaire. Due to the Covid-19 pandemic, these students completed their learning using distance learning options offered by the Ministry of Education after the closure of the schools. The table (1) shows the distribution of the participants according to their gender, grade level and experiences in dealing with distance learning. 
Table 1. Distribution of the participants according to gender, grade level and experiences in dealing with distance learning

\begin{tabular}{|c|c|c|c|}
\hline & Categories & Frequencies & Percentages \\
\hline \multirow[t]{2}{*}{ Gender } & Male & 648 & 64.0 \\
\hline & Female & 365 & 36.0 \\
\hline \multirow[t]{3}{*}{ Grade Level } & $10^{\text {th }}$ & 258 & 25.5 \\
\hline & $11^{\text {th }}$ & 291 & 28.7 \\
\hline & $12^{\text {th }}$ & 464 & 45.8 \\
\hline \multirow{5}{*}{$\begin{array}{ll}\text { Tools used in } \\
\text { Distance Learning }\end{array}$} & TV Screen & 18 & 1.8 \\
\hline & Desktop Computer & 15 & 1.5 \\
\hline & Laptop Computer & 99 & 9.9 \\
\hline & Tablet & 26 & 2.6 \\
\hline & Smartphone & 855 & 84.4 \\
\hline \multirow{4}{*}{$\begin{array}{lr}\text { Channels and } \\
\text { Platforms used in } \\
\text { Distance learning }\end{array}$} & Educational Ain Channels on TV & 19 & 1.9 \\
\hline & Educational Ain Channel on YouTube & 91 & 9.0 \\
\hline & Unified Education System & 375 & 37.0 \\
\hline & Future Gate & 528 & 52.1 \\
\hline \multirow{3}{*}{$\begin{array}{lll}\text { Daily Hours of } \\
\text { Distance Learning }\end{array}$} & 1-3 hours & 41 & 4.0 \\
\hline & 4-6 hours & 551 & 54.4 \\
\hline & More than (6) hours & 421 & 41.6 \\
\hline
\end{tabular}

\subsection{Instrument}

To answer the questions of the study, an online questionnaire was prepared by the researcher according to the educational literature and related previous studies discussed the interaction levels in online learning environments (Bouhnik and Marcus, 2006; Kuo et al., 2014; Moore, 1989; Wanstreet, 2006).

The questionnaire contained in its final form (24) statements distributed equally to four levels of interaction. The first level consisted of statements related to student-platform interaction, the second level consisted of statements related to student-content interaction, the third level consisted of statements related to student-teacher interaction and the fourth one consisted of statements related to student-student interaction. The validity of the questionnaire was checked according to the opinions of the experts in the field and its reliability was measured by calculating the Cronbach alpha coefficient values. The total Cronbach alpha coefficient value is 0.94 and that means the questionnaire is highly reliable.

To measure the participants' responses, a five-Likert scale was adopted. The scale contained the following categories: very high, high, moderate, low, and very low. The scores used for these categories were 5, 4, 3, 2 and 1 respectively and the following statistical criteria was used to classify the means: 1.00 - 1.80: very low, 1.81 2.60: low, 2.61 - 3.40: moderate, $3.41-4.20$ : high and $4.21-5.00$ : very high.

\section{Results}

\subsection{Results related to the first question}

Q.1: What is the extent of the interaction level of high school students with distance learning in a Saudi context? To answer this question, the researcher calculated means and standard deviations for the interaction levels jointly and separately. Table (2) presents these values.

Table (2): Means and standard deviations for measuring the interaction levels of high school students with distance learning in a Saudi context

\begin{tabular}{|l|l|l|l|l|}
\hline Category & Mean & Std. & Rank & Level \\
\hline Student-platform interaction & 3.47 & 0.65 & 3 & High \\
\hline Student-content interaction & 3.93 & 0.83 & 1 & High \\
\hline Student-teacher interaction & 3.53 & 1.03 & 2 & High \\
\hline Student-student interaction & 3.43 & 1.12 & 4 & High \\
\hline Total & 3.59 & 0.76 & High & \\
\hline
\end{tabular}

Based on table (2), it was found that the overall interaction level of high school students with distance learning in a Saudi context is high. That is because the total mean is 3.59 and the total standard deviation is 0.76 . Student-content interaction and student-teacher interaction are ranked first and second respectively whereas student-platform interaction and student-student interaction are ranked third and fourth respectively. The detailed results about each level of interaction are presented below:

1) - Student-platform interaction level:

To explore the student-platform interaction level of the respondents, means and standard deviations were calculated. Table (3) presents these means and standard deviations: 
Table (3): The means and standard deviations of the student-platform interaction level of the respondents

\begin{tabular}{|l|l|l|l|l|l|}
\hline No. & Statement & Mean & Std. & Rank & Level \\
\hline 1 & I can access the distance learning platform at any time. & 3.47 & 1.07 & 3 & High \\
\hline 2 & I can access the distance learning platform from anywhere. & 3.26 & 1.12 & 5 & Moderate \\
\hline 3 & $\begin{array}{l}\text { I follow the guidelines on how to deal with the distance learning } \\
\text { platform. }\end{array}$ & 3.88 & 0.99 & 1 & High \\
\hline 4 & $\begin{array}{l}\text { I interact with the learning resources provided by the distance } \\
\text { learning platform. }\end{array}$ & 3.75 & 1.07 & 2 & High \\
\hline 5 & $\begin{array}{l}\text { I find it difficult to interact with the distance learning platform due } \\
\text { to the poor level of internet connection. }\end{array}$ & 3.38 & 1.31 & 4 & Moderate \\
\hline 6 & $\begin{array}{l}\text { I find it difficult to interact with the distance learning platform } \\
\text { because of my low level of technological skills. } \\
\text { Total }\end{array}$ & 3.24 & 1.22 & 6 & Low \\
\hline
\end{tabular}

Based on table (3), it was found that the student-platform interaction level of the respondents is high according to the total mean, which is within the range of (3.41-4.20) used in this study. The total standard deviation is 0.65 . Statement (3) is ranked first stated the following: (I follow the guidelines on how to deal with the distance learning platform) and its mean is 3.88 while statement (6) is ranked last stated the following: (I find it difficult to interact with the distance learning platform because of my low level of technical skills) and its mean is 2.24 .

2) - Student-content interaction level:

To explore the student-content interaction level of the respondents, means and standard deviations were calculated. Table (4) presents these means and standard deviations:

Table (4): The means and standard deviations of the student-content interaction level of the respondents

\begin{tabular}{|l|l|l|l|l|l|}
\hline No. & Statement & Mean & Std. & Rank & Level \\
\hline 1 & $\begin{array}{l}\text { I can access the educational content through the distance } \\
\text { learning platform. }\end{array}$ & 3.85 & 1.04 & 4 & High \\
\hline 2 & $\begin{array}{l}\text { I try to find out the objectives for each of the distance learning } \\
\text { lessons. }\end{array}$ & 3.71 & 1.11 & 5 & High \\
\hline 3 & $\begin{array}{l}\text { I follow the lessons provided through the distance learning } \\
\text { platform. }\end{array}$ & 3.62 & 1.21 & 6 & High \\
\hline 4 & $\begin{array}{l}\text { I participate in distance learning activities that contribute to the } \\
\text { educational content. }\end{array}$ & 3.89 & 1.11 & 3 & High \\
\hline 5 & $\begin{array}{l}\text { I interact with assignments related to the distance learning } \\
\text { lessons. }\end{array}$ & 4.25 & 0.98 & 1 & Very High \\
\hline 6 & $\begin{array}{l}\text { I interact with tests related to the content of distance learning } \\
\text { lessons. }\end{array}$ & 4.25 & 0.99 & 1 & Very High \\
\hline & Total & 3.93 & 0.85 & & High \\
\hline
\end{tabular}

Based on table (4), it was found that the student-content interaction level of the respondents is high according to the total mean, which is within the range of (3.41-4.20) used in this study. The total standard deviation is 0.85 . Statements (6) and (5) are both ranked first and their mean is 4.25 . Statement (6) stated the following: (I interact with tests related to the content of distance learning lessons) and statement (5) stated the following: (I interact with assignments related to the content of distance learning lessons).

3) - Student-teacher interaction level:

To explore the student-teacher interaction level of the respondents, means and standard deviations were calculated. Table (5) presents these means and standard deviations: 
Table (5): The means and standard deviations of the student-teacher interaction level of the respondents

\begin{tabular}{|l|l|l|l|l|l|}
\hline No. & Statement & Mean & Std. & Rank & Level \\
\hline 1 & $\begin{array}{l}\text { I can access the teacher through the distance learning } \\
\text { platform. }\end{array}$ & 3.46 & 1.29 & 3 & High \\
\hline 2 & $\begin{array}{l}\text { I interact with the lessons that the teacher offers through the } \\
\text { distance learning platform. }\end{array}$ & 3.84 & 1.14 & 2 & High \\
\hline 3 & $\begin{array}{l}\text { I submit my questions to the teacher through the distance } \\
\text { learning platform. }\end{array}$ & 3.37 & 1.32 & 4 & Moderate \\
\hline 4 & $\begin{array}{l}\text { I use the distance learning platform to tell my teacher about } \\
\text { my learning difficulties. }\end{array}$ & 3.34 & 1.33 & 5 & Moderate \\
\hline 5 & $\begin{array}{l}\text { I follow the teacher's guidance on how to practice distance } \\
\text { learning. }\end{array}$ & 3.97 & 1.09 & 1 & High \\
\hline 6 & $\begin{array}{l}\text { I share my thoughts with the teacher through the distance } \\
\text { learning platform. }\end{array}$ & 3.21 & 1.42 & 6 & Moderate \\
\hline Total & 3.53 & 1.03 & & High \\
\hline
\end{tabular}

Based on table (5), it was found that the student-teacher interaction level of the respondents is high according to the total mean, which is within the range of (3.41-4.20) used in this study. The total standard deviation is 1.03. Statement (5) is ranked first stated the following: (I follow the teacher's guidance on how to practice distance learning) and its mean is 3.97 while statement (6) is ranked last stated the following: (I share my thoughts with the teacher through the distance learning platform) and its mean is 3.21 .

4) - Student-student interaction level:

To explore the student-student interaction level of the respondents, means and standard deviations were calculated. Table (6) presents these means and standard deviations:

Table (6): The means and standard deviations of the student-student interaction level of the respondents:

\begin{tabular}{|l|l|l|l|l|l|}
\hline No. & Statement & Mean & Std. & Rank & Level \\
\hline 1 & I can access classmates through the distance learning platform. & 3.36 & 1.36 & 4 & Moderate \\
\hline 2 & $\begin{array}{l}\text { I submit my questions through the distance learning platform to } \\
\text { classmates. }\end{array}$ & 3.23 & 1.34 & 6 & Moderate \\
\hline 3 & $\begin{array}{l}\text { I interact with the ideas offered by classmates through the distance } \\
\text { learning platform. }\end{array}$ & 3.39 & 1.32 & 3 & Moderate \\
\hline 4 & $\begin{array}{l}\text { I share my thoughts with classmates through the distance learning } \\
\text { platform. }\end{array}$ & 3.26 & 1.36 & 5 & Moderate \\
\hline 5 & $\begin{array}{l}\text { I work with classmates to do assignments related to the distance } \\
\text { learning lessons. }\end{array}$ & 3.64 & 1.32 & 2 & High \\
\hline 6 & $\begin{array}{l}\text { I encourage classmates to interact with distance learning lessons. } \\
\text { Total }\end{array}$ & 3.68 & 1.28 & 1 & High \\
\hline
\end{tabular}

Based on table (6), it was found that the student-student interaction level of the respondents is high according to the total mean, which is within the range of (3.41-4.20) used in this study. The total standard deviation is 1.12. Statement (6) is ranked first stated the following: (I encourage classmates to interact with distance learning lessons) and its mean is 3.68 while statement (2) is ranked last stated the following: (I submit my questions through the distance learning platform to classmates) and its mean is 3.23 .

\subsection{Results related to the second question}

Q.2: Are there any statistical differences in the responses of high school students in a Saudi context regarding the interaction level with distance learning related to gender differences?

To answer this question, T-test was calculated as it shown in table (7) below:

Table (7): T test for identifying the differences between the respondents interaction level due to gender

\begin{tabular}{|c|c|c|c|c|c|c|}
\hline Category & Gender & Frequencies & Mean & Std. & $\mathrm{T}$ value & Sig. \\
\hline \multirow[t]{2}{*}{ Student-platform interaction level } & Male & 648 & 3.44 & 0.66 & \multirow[t]{2}{*}{2.04} & \multirow[t]{2}{*}{0.041} \\
\hline & Female & 365 & 3.53 & 0.65 & & \\
\hline \multirow[t]{2}{*}{ Student-content interaction level } & Male & 648 & 3.87 & 0.86 & \multirow[t]{2}{*}{3.19} & \multirow[t]{2}{*}{0.001} \\
\hline & Female & 365 & 4.03 & 0.76 & & \\
\hline \multirow[t]{2}{*}{ Student-teacher interaction level } & Male & 648 & 3.43 & 1.05 & \multirow[t]{2}{*}{4.06} & \multirow[t]{2}{*}{0.000} \\
\hline & Female & 365 & 3.71 & 0.97 & & \\
\hline \multirow[t]{2}{*}{ Student-student interaction level } & Male & 648 & 3.34 & 1.15 & \multirow[t]{2}{*}{3.38} & \multirow[t]{2}{*}{0.001} \\
\hline & Female & 365 & 3.58 & 1.03 & & \\
\hline \multirow[t]{2}{*}{ Total Degree of Interaction } & Male & 648 & 3.52 & 0.79 & \multirow[t]{2}{*}{3.99} & \multirow[t]{2}{*}{0.000} \\
\hline & Female & 365 & 3.71 & 0.70 & & \\
\hline
\end{tabular}


Based on table (7), the values of $(\mathrm{T})$ at all interaction levels and the total degree of interaction are statistically significant at a level of $(a \leq 0.05)$. Thus, these results indicate that there are statistically significant differences in the interaction level with distance learning due to gender differences between high school students in a Saudi context, and these differences are in favor of female students.

\section{Discussion}

The main aim of this study is to discover the interaction level of high school students with distance learning in a Saudi context. The overall interaction level with distance learning among high school students was found to be high including student-content interaction, student-teacher interaction, student-platform interaction and studentstudent interaction.

The overall levels of student-content interaction and student-teacher interaction with distance learning were found to be high and these two interactions were ranked first and second respectively. The researcher attributes this result to the traditional model of teaching and learning, which is content-centered and guided by the teacher, and high school students are more familiar with this model and they depend on it during their distance learning process. This result is supported by previous studies conducted at online high school settings such as the study of (Borup et al., 2013) that found high school students perceived student-teacher and student-content interactions to have higher educational value compared to the other types of interactions, the study of (Turley and Graham, 2019) which found high school students perceive higher levels of student-teacher and student-content interactions in online high school courses and the study of (Zhang and Lin, 2020) that emphasized the importance of student-content interaction in online high school settings.

However, the overall levels of student-platform interaction and student-student interaction with distance learning were also found to be high but these two interactions were ranked third and fourth respectively. The researcher attributes that high school students may have higher desire to interact with their classmates through online learning platform but they sometimes face some challenges such as network disconnection. In addition, some of these students may not have enough experiences to interact with their classmates through online learning platform. Some results of this study are supported by the previous study of (Zucker, 2005) that found student-student interaction is an important motivational factor in online high school settings. In addition, students need more guidance and support on how to interact effectively through online learning platforms (Blaine, 2019; Bouhnik and Marcus, 2006).

It was also found that there were statistically significant differences in the interaction levels with distance learning due to gender differences between high school students in a Saudi context, and these differences were in favor of female students. The researcher attributes that female students may be highly motivated to engage with distance learning options. Lowes, Lin and Kinghorn (2016) found that female students are more active than male ones in online high school courses.

\section{Conclusion}

The present study addressed the interaction levels of high school students with distance learning in a Saudi context. These levels must be introduced, managed and evaluated in different online high school settings. Based on the results of the study, student-content interaction and student-teacher interaction are recommended to have priorities in distance learning environments that deal with high school students. In addition, these students need more educational guidance and technological support to interact effectively with their classmates through distance learning platforms. Finally, teachers and educational designers must take into account the gender differences of high school students in interaction levels with distance learning.

\section{References}

Alshehri, A. A. (2017). The perception created of online homework by high school student, their teacher and parents in Saudi Arabia. Journal of Education and Practice, 8(13), 85-100.

Blaine, A. M. (2019). Interaction and presence in the virtual classroom: An analysis of the perceptions of students and teachers in online and blended advanced placement courses. Computers and Education, 132, 31-43. https://doi.org/10.1016/j.compedu.2019.01.004

Borup, J. (2016). Teacher perceptions of learner-learner engagement at a cyber high school. International Review of Research in Open and Distance Learning, 17(3), 231-250. https://doi.org/10.19173/irrodl.v17i3.2361

Borup, J., Graham, C., and Davies, R. (2013). The nature of adolescent learner interaction in a virtual high school setting. Journal of Computer Assisted Learning, 29(2), 153-167. https://doi.org/10.1111/j.13652729.2012.00479

Bouhnik, D., and Marcus, T. (2006). Interaction in distance-learning courses. Journal of the American Society for Information Science and Technology, 57(3), 299-305.

Hawkins, A., Graham, C. R., Sudweeks, R. R., and Barbour, M. K. (2013). Academic performance, course 
completion rates, and student perception of the quality and frequency of interaction in a virtual high school. Distance Education, 34(1), 64-83. https://doi.org/10.1080/01587919.2013.770430

Kuo, Y. C., Walker, A. E., Schroder, K. E. E., and Belland, B. R. (2014). Interaction, internet self-efficacy, and self-regulated learning as predictors of student satisfaction in online education courses. Internet and Higher Education, 20, 35-50. https://doi.org/10.1016/j.iheduc.2013.10.001

Lowes, S., Lin, P., and Kinghorn, B. R. C. (2016). Gender differences in online high school courses. Online Learning Journal, 20(4), 100-117. https://doi.org/10.24059/olj.v20i4.1049

Moore, M. G. (1989). Editorial: Three types of interaction. American Journal of Distance Education, 3(2), 1-7. https://doi.org/10.1080/08923648909526659

Strategic Gears. (2020). Saudi response to the COVID19 pandemic. Available at: https:/www.strategicgears.com/wp-content/uploads/2020/04/Saudi-Response-to-the-COVID19Pandemic.pdf

Suwono, H., and Dewi, E. K. (2019). Problem-based learning blended with online interaction to improve motivation, scientific communication and higher order thinking skills of high school students. In AIP Conference Proceedings (Vol. 2081, No. 1, p. 030003). AIP Publishing. https://doi.org/10.1063/1.5094001

Turley, C., and Graham, C. R. (2019). Interaction, student satisfaction, and teacher time investment in online high school courses. Journal of Online Learning Research, 5(2), 169-198.

UNESCO. (2020). COVID-19 educational disruption and response. Available at: https://en.unesco.org/covid19/educationresponse

Wagner, E. D. (1994). In support of a functional definition of interaction. American Journal of Distance Education, 8(2), 6-29. https://doi.org/10.1080/08923649409526852

Wanstreet, C. E. (2006). Interaction in online learning environments: A review of the literature. Quarterly Review of Distance Education, 7(4), 399-411.

Zhang, Y., and Lin, C. H. (2020). Student interaction and the role of the teacher in a state virtual high school: What predicts online learning satisfaction? Technology, Pedagogy and Education, 29(1), 57-71. https://doi.org/10.1080/1475939X.2019.1694061

Zucker, A. (2005). A study of student interaction and collaboration in the virtual high school. In R. Smith, T. Clark, \& R.L. Blomeyer (Eds.), A synthesis of new research on K-12 online learning (pp. 49-52). Naperville, IL. Learning Point Associates.

Dr. Adam Shami Abdu Al-Amri The author of this paper holds a PhD in the field of curriculum and instruction from King Khalid University (KKU) in Saudi Arabia. He is currently working at Al-Qunfudah Educational Directorate as an educational director. His key interests are teacher professional development, secondary education and educational technology. He is an author of an Arabic book called "Teaching and Learning in Digital Age". He has published papers, particularly in the field of education technology, in conferences and journals. 